\title{
A Rehabilitative South African Criminal Law Response to Nyaope, Drug Addiction: - A Recommendation for Health Oriented Nyaope Drug Weaning
}

\author{
Mampolokeng Mathuso Mary-Elizabeth Monyakane* \\ Advocate of High Court of South Africa, University of South Africa (UNISA), South Africa \\ *Corresponding author: Mampolokeng Mathuso Mary-Elizabeth Monyakane, Advocate of the High Court of South Africa, is a Senior Lecturer at the \\ University of South Africa (UNISA), South Africa
}

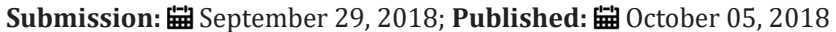

\begin{abstract}
Based on Prevention of Substance Abuse Master Plan objective, this article suggests ways in which the problem of Nyaope drug abuse among South African youths can be remedied. As opposed to purely criminal justice-oriented approaches, it proposes forensic care processes.
\end{abstract}

Keywords: Forensic care; Nyaope drug addiction; Criminalisation of addiction; Opioids; Marijuana

\section{Introduction}

Many South African youths are exposed to Drug abuse due to stress related experiences. Research regarding prevalent abuse of new designer drugs such as Nyaope in South Africa, shows that, Nyaope abuse has led to the escalation of drug abuse. Drug abuse is thus a major problem second to AIDS epidemic in South Africa. To remedy this problem South Africa sought a solution in Criminal Law amongst other attempts. The current South African Criminal Law remedy against drug abuse is punishment through direct imprisonment. This approach has not healed the drug abuse situation and yields no hope for drug addicts' rehabilitation. This article suggests what should be done with the hope to expose possible positive rehabilitation of drug abusers as opposed to punishing them without healing them. The study is intended to help with suggestion for early interventions for current and potential Nyaope drug abusers.

Based on the substance abuse prevention objective ensconced in the South African prevention of substance abuse Master Plan, this article suggests ways in which the problem of Nyaope drug abuse among South African youth can be remedied. It anticipates a health-oriented approach in rehabilitating Nyaope addicts. It draws examples from available non-academic literature on Nyaope abuse in South Africa. Mindful that few law specific articles and books related to Nyaope abuse are available, the article draws legal perspectives on Nyaope abuse from a few on-line reported cases.

It refers to newspaper's comments, conference proceedings and online-published audio media debates containing conversations by public and Nyaope addicts. All the information of focus concerns the scourge of Nyaope in several metropolitan areas in South Africa. The article draws from these discussions information that it uses to analyse the impact of legislative criminalisation of Nyaope drug abuse. It finds out if criminalisation of Nyaope designer drug tallies with the objective of South African Master Plan for curbing substance abuse.

\section{Background}

Nyaope is a concoction of dependence producing substances such as dagga and heroin as well as some of domestic toxic chemicals. Nyaope (It is a Tswana word meaning Mishmash-a useless thing. Once addicted you turn into a useless thing) drug bears other names depending on the location of exchange. The name Nyaope originated in Gauteng Province, Tshwane South Africa. In KwaZulu Natal South Africa, Nyaope is called Woonga. (This name is due to the sound it makes as it penetrates the abuser's mental parts.) It has differing trends of mixtures. (Monyakane MMME, $2016[1,2])$. (Weich L et al. [3]) commented on the lack of clarity concerning "the exact content of the street drug, "Woonga"." According to them, "woonga consists of a number of different substances, that may include heroin, crystal methamphetamine as well as rat poison and antiretroviral medications, specifically efavirenz." It is however clear that predominant ingredient among the available drug trends is dagga (dagga is locally known as matekoane. Other names for dagga are marijuana, weed etc) and heroin. Local producers access heroin from stolen television plasma screens, [4,5] and illegally plough dagga if not buy it from illegal backyard markets. (Ploughing and selling dagga is illegal in South African Law. There are however 
on-going debates and cases before courts in South Africa regarding legalization of marijuana consumption. See Dagga Trial, 7 August 2017 http://www.sabc.co) Recently on the 18 September 2018, the South African Constitutional Court has handed down judgment that legalized the private use of dagga. (See, Minister of Justice and Constitutional Development and Others v Prince (Clarke and Others Intervening); National Director of Public Prosecutions and Others v Rubin; National Director of Public Prosecutions and Others v Acton (CCT108/17) [2018] ZACC 30) [6].

Compared to common street drugs- crack cocaine and methamphetamine- Nyaope is more toxic and dangerously affects the abuser's mental health. To make matters worse, Nyaope is easily accessed than these other drugs. [7] Most of the unemployed youth who are also from the disadvantaged backgrounds can afford buying Nyaope and some of these youth are participating in manufacturing it. A fix of Nyaope sells from an amount of R20.00-R30.00, an equivalent of US\$2.00. [7] It was reported that the youngest of these abusers was a 12 years old minor and a child of a parent who is a Nyaope addict.

Another incidence captured in Monyakane MMM's [1,2] article is that of a seventeen years old girl whose story appeared in the local newspaper, (Sowetan, 2015) [8] where she explained that she was selling her body to get a fix of Nyaope. She explained further that she abused Nyaope since the age of thirteen. These reports are just a tip of an iceberg to statistics of youth in a similar situation $[1,2]$.

Many South African youth are exposed to drug abuse due to various reasons including stress related experiences. The unemployed youth who are also from the disadvantaged backgrounds seek solace into this drug as they consider it a form of stress relief [9] also read [1,2]. The drug is widespread and is sweeping across the unemployed millions of youth in South Africa, especially those around towns.

Drug abuse is thus a major problem second to HIV/AIDS epidemic in South Africa. At the forefront of drug abuse is the use of Nyaope drug [7]. Research regarding the prevalent abuse of new designer drugs such as Nyaope in South Africa, shows that, Nyaope abuse has led to the escalation of drug abuse and crimes statistics $[1,2]$.

To remedy this problem South Africa sought a solution in Criminal Law amongst other attempts (DOJ The Law to be amended to criminalise 'Nyaope', 2013 [10]). The current South African Criminal Law remedy against drug abuse is normal prosecution and punishment through direct imprisonment [1,2].

Regardless of these efforts, as many criminals whose Nyaope drug abuse underlie their criminality are being locked away, many more abusers that are new hit the streets $[1,2,10]$.

It is against this background that this article argues that the criminal justice-oriented perspective is wanting. An opinion that supports this argument is that locking away drug abusers does not yield a beneficial remedy to drug abuse. This view supports the observation that direct imprisonment does not deter potential abusers. It is a post active way of curbing Nyaope addiction among South African youth. It is therefore important to suggest ways in which the problem of Nyaope drug abuse among South African youth can be remedied to nip it on the bud. Innovative means interacting the criminal justice legal processes with early involvement of medical expertise that administer medication for depression and stress related conditions seems to be of importance in this regard. It is through this approach that the objective of South African Master Plan for curbing substance abuse would be realised.

\section{The South African Drug Master Plan for Curbing Drug Addiction}

South Africa considers drug abuse a central threat to development, especially regarding youth. Drug abuse prevention became the centre of concern from the time South Africa gained democracy. The ensued social maladies of drug abuse have always haunted democratic South African leaders hence the expression in the National Drug Master Plan:

"In his first opening address to Parliament in 1994, South African President Nelson Mandela specifically singled out alcohol and drug abuse among the social pathologies that needed to be combated. Alcohol and other drug abuse (hereinafter referred to as substance abuse) is a major cause of crime, poverty, reduced productivity, unemployment, dysfunctional family life, political instability, the escalation of chronic diseases such as AIDS and tuberculosis (TB), injury and premature death. Its sphere of influence reaches across social, racial, cultural, language, religious and gender barriers and, directly or indirectly, affects everyone" [11-13].

With these fears on mind, South Africa adopted a master plan ensconcing fundamentals of drug abuse prevention among South African youth. The initial stage had entailed broad opinions from a broad spectrum (The involved brains came from; Office of the Attorney-General, Western Cape; South African Alliance for the Prevention of Substance Abuse (SAAPSA) Department of Welfare; Alcohol and Drug Studies, Johannesburg South African Narcotics Bureau (SANAB) South African Revenue Service (SARS); Mental Health and Substance Abuse, Department of Health; South African National Council on Alcoholism and Drug Dependency (SANCA) Medical Research Council (MRC); Human Science Research Council (HSRC); National Crime Prevention Strategy, Programme Management Services, Department of Welfare; Department of Education Department of Foreign Affairs; Department of Correctional Services Roads and Transport Technology, CSIR; Medicines Control Board; Department of Health; Department of Justice). The approach that entailed broad opinions ought to have given hope that the ultimate efforts in curbing drug abuse would be inclusive of the rest of the broad professional opinions involved from the planning stages. Nevertheless, the objective of inclusive planning approach against drug abuse was not accusatory of drug abusers. First, the group appreciated the reasons for possible excessive drug abuse in South Africa and acknowledged that South African challenges are not unique to South Africa. The master plan in this regard states that: 
a) "South Africa is, for a number of reasons, experiencing an unacceptable increase in substance abuse (the age of first experimentation has also dropped) and its associated problems.

b) Principal among them is the social and political transformation which has taken place on the domestic front, and our re-emergence as a member of the international community.

c) The rapid expansion of international air links, combined with the country's geographic position on major trafficking routes between East Asia and the Middle East, the Americas and Europe; a well-developed transportation infrastructure; modern international telecommunications and banking systems; long, porous borders and weak border control have made South Africa a natural target for drug traffickers.

d) Desperate and unemployed South Africans are being lured by syndicates with promises of easy money into becoming drug couriers and the overflow of drugs transhipped through South Africa is also finding its way onto the local market.

e) With regard to tobacco, the National Cancer Registry estimates that about 89000 premature deaths per year can be expected in South Africa on the basis of current smoking patterns.

f) South Africa is not alone in its fight against drugs. The rapid globalisation of the drug trade over the past decade has virtually assured that no country is immune to the threat, and a growing number are developing long-term strategies to deal with the problem. The successes of these strategies, however, necessarily imply the increased threat to the South Africa's borders, as drug traffickers are forced to find markets further afield in which to ply their wares," [11-13].

Informed by these reasons the master plan objective and aims amongst others single out the need to focus on youth and crime. It recognised that in most cases the youth is vulnerable. It suggests that youth engages in crime, due to abuse of drug with the aim to feed drug addiction. The chickens have now come home to roost with current high statistics of youth abusing Nyaope designer drug in South Africa.

In similar cases, the plan highlights establishment of diversion programmes. It recognises the need for capacity building in the courts of law for dealing with drug-related offences. The plan therefore creates a foundation upon which role occupants who deal with cases that are related to drug abuse may seek guidance. At this hint, it would suffice that drug addicts who are criminals would not be dealt with within the normal harsh criminal justice system as it is currently happening. The investigation and prosecution of these categories of criminals would call for a different cause. Insisting on normal procedures is tantamount to the ignorance of the addiction problem which if solved; there would be a decrease in criminal behaviours. In a nutshell, punishing Nyaope addicts through criminal law punishment prescripts does not bear any rehabilitation of the addicts. In this situation, the medical professional perspectives would be of assistance.

\section{The Health-Oriented Drug addiction Treatment}

Scientifically, drug addiction is explained to be a chronic disease because of its effects on human brain [9,3]. Addiction to Nyaope as an example has severe withdrawal symptoms compared to other designer drugs such as crack cocaine and methamphetamine. Once engulfed Nyaope is not easy to quit because of its heroin component effects. If a wrong approach towards weaning a Nyaope addict, is used such an addict normally relapses with severe consequences calling for treatment. Avoiding immediate medical attention for addicts would be like reinventing a wheel at the expense of rearing addicts who are difficult to heal [3]. Nyaope treatment is difficult and hence the need for health-oriented treatment that needs suitable plans from the onset. This means that unlike it currently happens, arrested addicts ought to be submitted to treatment immediately and not be thrown into custody to await their trials and subsequently use addiction as mitigation upon sentencing. The recent unreported Director of Public Prosecutor (DPP) decision on representations concerning the magistrate court case no 14/303/2017 [14] State v Curtis Adams and Imran Adams (the Adams brothers' case) bears an example on how the criminal justice system currently treats Nyaope addicts. The synopsis of the representation is that the Adams brothers are arrested on allegations of house breaking among others in that they have broken into their home and stole property of their parents. Their mother reported to the police that her children are addicted to nyaope and that they commit an array of crimes so as to get cash and feed their addiction. The police arrested the two brothers and bail was never attempted. The accused's mother in her statement to police mentioned that she needs her sons to be kept in custody so that they get the necessary help against their nyaope drug addiction.

Defence counsel then approached the DPP and sought that the two brothers find the necessary help. To do that counsel suggested that the state withdraws the criminal prosecution and use discretion to commit the accused to necessary health care. The representations were couched in the following way:

\section{Introduction}

a. These representations seek withdrawal of the matter and a directive for rehabilitation in terms of the Prevention of and Treatment for Substance Abuse Act, Act 70 of 2008 [15] (herein after PTSA Act).

b. In chapter 8, the PTSA Act provides for involuntary treatment of patients with substance use disorders where several circumstances exist.

c. First, if they are a danger to themselves or their immediate environment. Second, if they pose a major public health risk. Third, if they cause harm to their welfare or the welfare of their families. Fourth, if they cause harm on other members of the society through any means including using crime as a way to sustain their drug habit. 


\section{Facts of the matter}

I. The complainants in this matter are the parents of the accused persons. Mainly the stepfather who complains that the accused broke into his home where he stays with their mother and stole property

II. The mother confirms that the two boys steal property. She mentions that they do so in order to sell the property so that they can buy drugs

III. The accused have track record of abusing drugs-(Nyaope/ heroin)

IV. The mother says that the boys are willing to go for rehab but she does not have means to help them. She pleaded that they be kept in custody so that they access treatment/rehabilitation from using drugs

V. Due to their drug problem they dropped out of school

VI. They do not work

VII. They therefore steal to feed their habit of smoking heroin

VIII. Thus indeed the underlying reason to keep the accused in custody is to rehabilitate them. With unavailable avenues to help in the situations that these parents faced, the parents have run to the criminal justice system. At least they could have police who could contain the accused. Further, the appeal is that the court would find the accused guilty of robbing their parents and then put them in jail where hopefully they would access the professionals who would help the parents and provide medical care that weans the accused from smoking Nyaope/heroin.

\section{Submissions}

a) Counsel appreciates the predicament faced by parents to the accused persons. Currently the truth is that the there are no systems in place to answer the problem of crime associated with drug addiction. While courts in most cases would deal with the criminal aspect part and ultimately punish the accused based on the criminal justice prescripts the main problem of drug addiction is addressed as a by the way issue and yet it is a central issue.

b) In some respect where medical professionals were able to raise a word. They have disagreed with the current procedure of using the criminal justice system where rehabilitation issues are at stake like in the current case.

c) Their concern are that the current systems work in silos at the detriment of failing in their objective of weaning drug addicts so that drug related crimes are done away with.

d) The process followed by courts has proven to be a time consuming process starting with a sworn statement to the public prosecutor at the Magistrates court.

e) The same process has been criticised as breeding more problems because once the addicts are arrested, they are subjected to sudden withdrawals from drug doses. These sudden withdrawals cause the drug rehabilitation processes to be difficult due to the worsened mental f) The process interferes with the medical treatment cycle of patient treatment based on appropriate plans.

g) This may cause further mental complications as the suspect is forced into unsupervised withdrawal. Drug addiction causes damage to the brain and thus change behavior of addicts. Involuntary withdrawals normally lead to prolonged side effects [3].

h) (Leshner, 1997:1) observed that drug addicts behave like other sufferers of brain diseases because, "drug addiction has embedded behavioural and social-context aspects that are important parts of the disorder itself." She considers the most effective treatment approaches to be those including, "biological, behavioural, and social-context components."

i) The current committal of the accused has not offered these to the accused.

j) They accused indeed confirmed that they suddenly withdrew from smoking Nyaope/heroin as soon as they were arrested.

k) There is not yet any treatment whatsoever offered to them since their arrest.

l) It suffices that they are now exposed to a further mental damage due to unmonitored sudden drug withdrawals from heroin.

\section{Recommendation}

i. In the circumstances, it is eminent that the accused are diverted and sent for effective drug rehabilitation. If accused are left in the justice system as it is now happening. We are not going to achieve the objective of weaning them from drugs so that they become normal law-abiding citizens.

ii. Treating the accused within current prescripts of law would be denying the fact that our law is ailing. The current, state of facts is that, within the current state of nyaope abuse, a major statistics of criminals, especially of the perpetrators of crimes similar to the crimes perpetrated by the accused, are sufferers of drug addiction and if appropriate medical attention is not given to them, but they are dealt with within the current criminal justice prescripts, the circle of criminality will be blamed on the missing link between our law and the related health oriented professionals.

iii. Your offices can break this circle while a new law or appropriate procedures are suggested.

iv. Your urgent and considerate attention in the current matter can cure the current circle inferred by the legal profession's ignorance of the impact of drug abuse on the criminal justice system."

The DPP disagreed with the defence counsel in the light that there were no direct laws that support the proposals of the defence counsel. The DPP argued that the case docket disclosed a prima facie case to which both accused had a case to answer. While the DPP agreed that, the Criminal Justice System is often used for rehabilitation issues, the DPP's decision to the representations reflected an assessment based on the merits of the matter and upon 
which the DPP found no reasons "in fact and law" to sanction the withdrawal of the charges against the accused. The DPP argued that both accused were adults.

The DPP further affirmed that the courts and the other relevant government departments have limited resources for rehabilitation. In that stance a certain class of offenders, youth or minor persons are preferred over adult offenders in the utilization of these resources. The DPP argued further that the accused had previous convictions and therefore they were not suitable candidates for diversion.

Instead of viewing consistent crime commission by the accused in order to feed their addiction an aspect for urgent medical attention, the DPP referred to the state of accused's addiction in the negative. The DPP concluded that such a state could not gain the accused preference for rehabilitation. This aspect, the state treated as a mitigating factor. According to the DPP, defence counsel's representation dealt almost exclusively with the personal circumstances of the accused, which in the DPP's opinion serve as factors in mitigation of sentence after the accused went through the trial processes and not prior that.

The DPP further opined that under normal circumstances or where a first offender was concerned, it could be considered a non-custodial or correctional supervision type of sentence, with an option of a programme on rehabilitation. However, the DPP suggested the Adams brothers were not offending for the first time in the manner, which they did and therefore such sentences would not be suitable. This meant that the Adams brothers if found guilty were gunning for a heavier sentences without a consideration that the accused were committing the crimes so as to feed addiction and therefore a sign for need for medical attention.

It is submitted that the DPP missed the important issue, namely the essence of offending to feed addiction and the need for immediate health care on offenders who use crime to feed their addiction. In the absence of law that guides this need, it is argued in favour of scientific recommendations that there is a need for a most suitable treatment plan for drug addicts who are also offenders due to their addiction- that entails setting realistic goals [3]. These goals would help in matching respective Nyaope drug addicts with appropriate services. The plan would get rid of prolonged criminal justice processes, which practically distract from the immediate offering of intended services. As suggested, it is an ideal service for patients with opioid use disorders to offer an array of treatment options, including opioid free treatment with detoxification and relapse prevention strategies that may be either psychosocial or psychosocially assisted antagonist treatment, as well as psychosocially assisted opioid substitution treatment, offering a choice of full agonist and partial agonist substitute opioid. Treatment planning should include matching each patient to the most optimal treatment choice for that individual [3].

As opposed to these suggestions, in practice as seen from Adams brothers' case, winding processes normally occur where intended services are availed after approvals by courts like in criminal justice processes used in South Africa. Arrested Nyaope addicts, first undergo pre-trial processes, which are normally prolonged, and they are exposed to sudden withdrawals against medical recommendations. Atypical is the provision in chapter 8 of the Prevention of and Treatment for Substance Abuse Act, Act 70 of 2008 [15] (herein after PTSA Act). The PTSA Act provides for involuntary treatment of patients with substance use disorders where several circumstances exist.

First, if they are a danger to themselves or their immediate environment. Second, if they pose a major public health risk. Third, if they cause harm to their welfare or the welfare of their families. Fourth, if they cause harm on other members of the society through any means including using crime as a way to sustain their drug habit. As far as drug addicts' offenders are concerned their attention is subjected to the court processes either an enquiry or an evaluation before criminal court Magistrate. Concisely PTSA Act authorises a process that delays drug addicts' medical attention. It prescribes that attention may be availed after an enquiry by the legal professionals- the prosecutors who are clothed with discretions regarding whether the offender addict can be given medical attention and thus divert them from a normal criminal justice process. This discretion is even limited in that it is exercised in cases where direct imprisonment is not eminent.

It is submitted that this approach cause discomfort as it affects health professionals negatively. It is unnecessary statutory interference and appears to be antithesis medical professional ethics towards a speedy attention to addicts. It exposes that as far as the rehabilitation of drug addicts' offenders, South Africa has legal prescripts, which do not speak to the practical health-oriented rehabilitation processes. There has been an outright condemnation, regarding the application of the PTSA Act. Concerned health professionals viewed it to be hampering immediate attention to needy patients [3].

In the midst of these important calls, the Act requires committal of the suspects. This has proven to be a time-consuming process starting with a sworn statement to the public prosecutor at the Magistrates court. The process interferes with the medical treatment cycle of patient treatment based on appropriate plans. This may cause further mental complications as the suspect is forced into unsupervised withdrawal. Drug addiction causes damage to the brain and thus change behaviour of addicts. Involuntary withdrawals normally lead to prolonged side effects [3].

(Leshner 1997:1) observed that drug addicts behave like other sufferers of brain diseases because, "drug addiction has embedded behavioural and social-context aspects that are important parts of the disorder itself." She considers the most effective treatment approaches to be those including, "biological, behavioural, and social-context components." In consonance to her submission, The South African National Drug Master Plan implies that the one-sided approach in rehabilitating Nyaope addicts sought from current criminal justice system is full of complexities and neither heals the 
addict nor cure crime. The general approach penned in the Master Plan is acceptance that "a single approach such as criminalising or decriminalising substances or abusers will not solve the problem. Instead, a number of strategies should be applied in an integrated way." [12] Punishment meted within the criminal punishment prescripts is short of all necessary mechanisms necessary for rehabilitating Nyaope drug addicts. To confirm this concern, Monyakane [1,2] explained the way courts deal with the punishment of Nyaope addicts once they are caught in drug related crimes. She related that when courts deal with "Nyaope addicts who sell Nyaope to sustain their addiction [they are] bound to apply sections 3, 4, 5, and 17 of Drugs and Drug Trafficking Act, while they observe and apply section 51 of the Minimum Sentences Act. Courts would then be limited to sentencing these abusers to direct imprisonment just like any other drug trafficker as the law demands. Their sentences would be tied to the restrictions of between 15-25 years imprisonment created by the legislature and with the demands of the Minimum Sentences Act they would not budge to less than 5 years imprisonment," [1,2].

This approach exposes challenges in the way Nyaope addicts who are involved in criminal acts are sought to be rehabilitated under the criminal justice system. This system is lacking possible health-oriented interventions proposed in the Master plan. Healthoriented interpretation of addiction exposes that even though drug addicts appreciate their criminal behaviour their behaviour is involuntarily [3]. Thus, Nyaope addicts' rehabilitation cannot suit criminal law perspectives of punishment but has to be addressed in terms of the master plan health-oriented objective [11-13]. At the fore is the need for involvement of health science professionals from the time when suspected Nyaope drug addicts are investigated. These would include among others, mental health nurses, psychiatrists; psychologists; social workers; specialized law professionals; occupational therapists and epidemiologists as well as specialized police who have essential skills. These professionals have to work together in investigating and prosecuting these specialized Nyaope addiction criminal cases.

\section{The Scientific Perspective on Nyaope Addiction Effects in Relation to the Criminalisation of Nyaope Addiction}

Nyaope addiction effects like other brain diseases as shown above are intertwined. Accordingly, from a medical oriented perspective, [3] explain the effects of opioid abuse. They relate that, "Opioid use disorders are of increasing public health concern worldwide. Severe opioid use disorders are mostly chronic and often life-long conditions that for many patients follow a relapsing and remitting pattern. The aetiology is multifactorial and includes a genetic contribution as well as environmental factors and individual determinants. It is not an illness of "lack of willpower or poor morals", but rather a complex biological disorder, that is associated with characteristic neurological abnormalities and associated behavioural changes. It is best viewed as a chronic health problem and is optimally treated via a chronic medical intervention model." In agreement with their explanation is [16] who explained the effects of heroin. Nyaope as a concoction can be suitably classified under opioid because of its heroin component. There is no scientific research regarding the percentage of heroin in the Nyaope component. Be that as it may, nyaope shares similar apprehensions to those raised regarding opioids. Its effects on individual mental health are extreme. It affects the mental health of an addict who in turn becomes a habitual criminal if not a pauper. The addicts in Pretoria and other metropolitan areas beg for money to feed addiction. Some addicts live from stealing private and public property to have money and secure the supply of Nyaope. Courts are flocked with these types of criminals $[1,2]$ observed that, " $[t]$ he sides effects to abusing Nyaope are multifarious. A plethora of criminal cases heard recently before courts of law in South Africa, reveal that the criminal perpetration in one way or another is connected to the abuse of Nyaope. In most cases these crimes are perpetrated so as to raise money and feed the addiction. Parents are caught selling babies for funds to buy Nyaope. Women are engaged in prostitution. In most cases crimes of theft, housebreaking and robbery as well as murder are perpetrated by Nyaope addicts. In a raid against Nyaope abusers performed by police in Kwazulu Natal, amongst the arrested majority of two thousand (2000) Nyaope abusers were persons who went through the criminal justice system."

Apart from arrest emanating from addicts' commission of multifarious crimes, addicts can be arrested for Nyaope possession. It is illegal in South Africa to harbour Nyaope concoction. Nyaope concoction ingredients are listed in Schedules I and II of the Drugs, and Drug Trafficking Act 140 of 1992 [17] (herein after referred to as the drugs and drug-trafficking Act). Sections 13(c) and (d) read with sections 4(a) and (b) as well as sections 17(b) and (d) of the drugs and drug-trafficking Act, criminalise and punish acts of possession and use of dependence -producing substances listed in the mentioned schedules. Whoever possesses Nyaope, including the drug addicts who hold it for consumption is guilty of possession of illegal drugs. If authority finds these addicts, they are arrested and charged before courts of law. The state of addicts arraigned before courts of law continue to be a challenge. Thus, the effects of addiction to Nyaope are that the abusers deteriorate in mental capability and physical health, which makes it difficult to really reasonably judge the extent of their criminal intent.

Criminal liability of a perpetrator is determined by the extent of the perpetrator's intention to commit crime. The fact that scientific exposures show that Nyaope addicts even though they appreciate their acts lack voluntariness impact on the criminal element of intention [18-20]. This raises alarm regarding the nature of punishment they are exposed to upon arrest. Nevertheless, there are divided feelings regarding how to deal with the Nyaope addicts criminals. Public including legal professionals are divided concerning the treatment that the Department of Justice recommended for the handling of criminal element related to Nyaope addiction. There are a few numbers of publicly declared Nyaope addicts' sympathisers.

A dominant population concern and legislatively acclaimed perspective is that Nyaope addicts are deliberately mischievous and have to be taught a lesson that will put them right [1,2,21-23]. From 
a criminal punishment perspective, Nyaope addicts are first treated as family outcasts by societies within which they are living in. Secondly, they are excluded from families. Thirdly, they are labelled with derogatory names such as "bo Nyaope," the Nyaopes (the mishmashes-useless and confused things- a name given from the nature of the designer drug-a mishmash). As if they are accepting of their low standard status, categories of these Nyaopes are seen begging money at the crossroads and town malls parking lots. Some volunteer to wash cars of passers-by for any donation from food cramps to fifty cents coin donations. At night, some of these beggars become thieves and robbers. They snatch handbags and rob cars. They break into houses and steal or even kill to secure property so that they can raise money for their addiction. Nyaope addicts hardly do any descent work. They want easy and quick money to feed their addiction. The aim of their activities is to maintain cash flow for buying Nyaope [7].

Furthermore, Nyaope addicts are arrested for possession of Nyaope and crime perpetration related to their addiction (One abuser exclaimed during interview that it is amazing that police come after abusers and never arrest the sellers even though sellers of Nyaope are well known, [7]) The overtly criminal behaviour overshadowed the state's initial plan to curb drug addiction and thus Nyaope addiction. Against the Master Plan, in order that the perpetrators of the crime of possession and use of Nyaope are brought to book, the South African government through its Department of Justice and Constitutional Development, (hereinafter the DOJ\&CD) vouched at its preparedness to fight Nyaope abuse. It reckoned that Nyaope use was steadily escalating and took upon itself to take formal measures to curb the use of Nyaope through legislative intervention. To carry out its mandate of weaning addicts of Nyaope, the DOJ\&CD designed legislative amendments on the Drugs and Drug Trafficking Act. It reformed the law through, "inserting Nyaope "ingredients" into Schedules I and II of the Act. According to Monyakane MMM [1,2] the DOJ\&CD law reform mechanisms had aimed at facilitating easy prosecution of "Nyaope related offences, entailing its possession and use." It was the intention of the DOJ\&CD to amend the Act by extending its application to substances, which were not criminalised before like Nyaope. The associated methodologies entailed two different approaches. Firstly, schedule II listing prohibited drugs was made to entail previously unlisted drugs. Secondly drugs mimicking the "pharmacodynamics properties - that has biochemical and physiological effects on a person, similar to the listed substances," were declared illegal to possess in terms of schedules I and II. Effectively, the amendment made substances similar in chemical composition and effects on the mental health of a person illegal. These included new substances mimicking the prohibited substances. At the end possession and dealing with any mixture, having effect similar to prohibited and illegal substances would attract criminal punishment of at least direct imprisonment [1,2].

The development was further equated to moves by advanced states such as the United States, where designer drugs similar to Nyaope were a problem. The argument was that currently, South African youth has a similar socialisation to associated changes in
American social culture (DOJ http://www.justice.gov.za/docs/ articles, 2015 [24], DOJhttp://www.justice.gov.za/m_statements, 2015 [25])

\section{Conclusion and Recommendations}

It would seem that the calamities ensued in the Nyaope abusers' dealings has led state to focus on punishment in order to curb Nyaope addiction regardless of what the Master Plan had proposed. This rushed move has left unattended the netty gritties of the objective in the drug addiction Master Plan. In agreement with the Master Plan proposals, it is submitted that, Nyaope addicts need help, not punishment. In the absence of proper drug addiction victims' diversion programmes in South African criminal justice system, the extension of the strict application of the drug trafficking control laws to abusers remains a challenge.

Direct imprisonment for Nyaope abuse has many failures attached to it. It does not deter potential abusers.It is tantamount to latching the stable door after the horse had bolted. Actually, the prosecution and sentencing of drug abusers within the normal justice system processes for the crime they had perpetrated due to Nyaope abuse is post active. It is worth of criticism that it is one sided. It lacks all anticipated drug abuse control objective, which were endorsed in the South African drug abuse prevention plan (The National Drug Master Plan 2013-2017 [12]).

In the midst of this dilemma, it is important that innovative means interacting the criminal justice legal processes with early involvement of medical expertise are employed. These may lead to the rehabilitation of drug abusers as opposed to punishing them without healing them. The new means will also help with early interventions for potential Nyaope drug abusers.

The innovative strategy must entail forensic care mechanisms. Currently South Africa has no forensic care facilities and professionals. If they are there, they are not working collaboratively. South African criminal investigation systems are still isolated and depend on Police and the Department of Justice. There is little collaboration between the Justice and Health departments. The police force tasked at investigating Nyaope related crimes have to be trained with specialised skills in identifying high-risk Nyaope cases. The specialised police force must aim at reducing individual self-harm and harm external to the Nyaope abusers. Police must work together with other mental health professionals, for example social workers, nurses and Psychologists [26-29].

The investigation will then be able to identify and mitigate risks for people affected by Nyaope addiction before the criminal justice system kicks in. Both long-term risks and short-term harms must be given attention as early as the initiation of crime investigation. Crime investigation in Nyaope related cases ought to involve several sectors and not police department alone. There is a need that the justice sector collaborates with the health care sector. Psychologist ought to be engaged in the early stages of investigation. These attempts would require the improvement of public centered forensic care centres [30-36]. 
The large institutions such as schools; universities; the government departments and related NGOs will have to partner in order to come up with effective outcomes. Investigating police officers must be open to working with other professionals such as social workers and psychologists to "identify and mitigate risks" for people affected by Nyaope abuse. These role occupants would contribute in assessing different aspects of the intertwined effects of Nyaope addiction [37-44]. Different professionals would be able to identify the combination of related factors, determine why the Nyaope abuse takes place, and predict the likelihood of future occurrences. The all-inclusive strategy will help in curbing the increasing statistics of Nyaope abusers. In the same manner, the crime statistics will decrease.

\section{References}

1. Monyakane MMM (2016) The South African drugs and drug trafficking act 140 of 1992 read with the South African criminal law amendment act 105 of 1997: an example of a one size fits all punishment? Criminal Law Forum 27(2): 227-254.

2. Monyakane MMME (2016) Irrationality in South African crime of possession and use of nyaope and its possible influences on the missing health-oriented state interventions for Nyaope addicts. J Addict Behav Ther Rehabil 5(4): doi: 10.4172/2324-9005.1000158.

3. Weich L, Perkel C, van Zyl N, Rataemane, Naidoo L (2015) South African guidelines for the management of opiod use disorders: South African Addiction Medicine Society (SAAMS).

4. Brendan R (2016) Plasma TV powder drug craze: crime and courts.

5. Ellis G, Stein D, Thomas K, Meintjies E (2015) Substance use and abuse in South Africa-insights from brain and behavioural sciences. Juta and Company (Pvt) LTD, South Africa.

6. Minister of Justice and Constitutional Development and Others v Prince (2018) (Clarke and Others Intervening); National Director of Public Prosecutions and Others v Rubin; National Director of Public Prosecutions and Others v Acton (CCT108/17). ZACC 30.

7. Mabusa N (2016) You tube ZA checkpoint EP19-Whoonga Special.

8. Nkosi N (2015) I Sell Sex for Nyaope: Nyaope Crisis Save Our Nation. Sowetan, South Africa.

9. van Heerden MS, Grimsrud AT, Seedat S, Myer L, Williams DR, et al (2009) Patterns of substance use in South Africa: results from the South African Stress and Health study. S Afr Med J 99(5Pt 2): 358-366.

10. http://www.dispatchlive.co.za/news/2013/03/09/Nyaope-hits-elstreets-and-addicts-cant-quit/

11. The South African National Drug Master Plan of 2006-2011.

12. The South African National Drug Master Plan 2013-2017.

13. The South African National Drug Master Plan of 1999.

14. State v Curtis Adams and Imran Adams case no 14/303/2017 unreported.

15. Prevention of and Treatment for Substance Abuse Act, Act 70 of 2008.

16. Kosten TR, George TP (2002) The neurobiology of opioid dependence: implications for treatment. Sci Pract Perspect 1(1): 13-20.

17. South African Drugs and Drug Trafficking Act 140 of 1992
18. Hippard J (1972) The Constitutionality of criminal liability without fault: an argument for a constitutional doctrine of mens rea houtson law review 10: 1039-1058.

19. Syre E (1932) Mens Rea, 45 Harvard Law Review 974, pp. 1004-1007.

20. Kemp G, Walker S, Palmer R (2013) Criminal Law in South Africa: Criminal Justice 121-133.

21. Collins F, Skeleton D (2014) Nyaope classification revives drug sentencing debate.

22. Allman G, Hugo J (2016) Concerns in Nkepile Mabusa You tube ZA checkpoint EP19-Whoonga Special.

23. Zuma J (2017) South Africa gets tough on substance abuse, speech delivered at the Summit on substance abuse, themed An Integrated Approach: Towards a Drug-Free Society, Department of Social Development and the Central Drug Authority, 15 to 17 March 2011.

24. DOJ (2015) The End for Nyaope! Republic of South Africa.

25. DOJ (2015) The Law to be amended to criminalise 'Nyaope'. Republic of South Africa.

26. (1997) Addiction is a brain disease, and it matters: Frontiers in neuroscience: The Science of Substance Abuse. Science 278(3): 45

27. Nester EJ, Malenka RC (2004) The addicted brain. Sci Am 290(3): 78-85

28. Warner-Smith M, Darke S, Lynskey M, Hall W (2001) Heroin overdose: causes and consequences. Addiction 96(8): 1113-1125.

29. 2012 World drug report. United Nations Office for Drugs and Crime. Vienna: United Nations, Austria.

30. Criminal Procedure Act 51 1977. Republic of South Africa.

31. South African Criminal Law Amendment Act 105 of 1997.

32. (2016) Jannie Hugo's interview and comments in Nkepile Mabusa's You tube ZA checkpoint EP19-Whoonga Special.

33. Mathoho M, Birts (2016) Nyaope addicts use Car wash business to sustain their addiction.

34. (2016) Shasha Wales Smith Devil-Bones Health.

35. (2016) Sinenhlanhla Mthembu Woonga Park Documentary Sinenhlanhla Mthembu.

36. You Tube ZA Bones: Cheap heroine grips SA's youth.

37. (2016) You Tube ZA Enca Whoonga addicts make unusual demand to city's bosses.

38. (2016) You Tube ZA Nyaope wreaks havoc in the lives of young women.

39. Letlalo V (2014) Minister of police (28575/12) [2014] ZAGPJHC 72 South Gauteng High Court, Johannesburg.

40. Moses V (2015) Minister of safety and security (6983/2013) [2015] ZAGPJHC 35 South Gauteng High Court, Johannesburg.

41. S V FM (2012) (A263/12) [2012] ZAGPPHC 180; [2012] 4 All SA 351 (GNP); 2013 (1) SACR 57 (GNP) (20 August 2012) North Gauteng High Court, Pretoria.

42. S V Mngenelwa (2015) (SS243/2015) [2015] ZAGPJHC 219 (15 May 2015). South Gauteng High Court, Johannesburg.

43. S V Ndau (2015) (A292/15) [2015] ZAGPPHC 274 (6 May 2015). North Gauteng High Court, Pretoria.

44. Sithebe V (2014) Minister of Police (31236/2012) [2014]. ZAGPJHC 201 South Gauteng High Court, Johannesburg 

(c) (1) $\begin{aligned} & \text { Creative Commons Attribution } 4.0 \\ & \text { International License }\end{aligned}$

For possible submissions Click Here

Submit Article

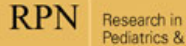
Pediatrics \&
Neonatology
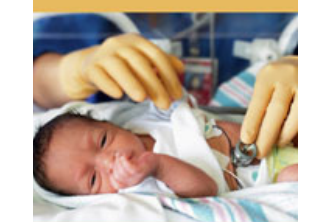
5.43

- Freely accessible online immediately upon publication

- Authors retain the copyright to their work

- Licensing it under a Creative Commons license

- Visibility through different online platforms 